\title{
Effect of Pretreatment of Intact 'Gala' Apple with Ethanol Vapor, Heat, or 1-Methylcyclopropene on Quality and Shelf Life of Fresh-cut Slices
}

\author{
Jinhe Bai \\ Oregon State University, Mid-Columbia Agricultural Research and Extension Center, Hood River, OR 97031 \\ Elizabeth A. Baldwin ${ }^{1}$ and Robert C. Soliva Fortuny \\ U.S. Department of Agriculture, Agricultural Research Service, Citrus and Subtropical Products \\ Laboratory, Winter Haven, FL 33881
}

James P. Mattheis

U.S. Department of Agriculture, Agricultural Research Service, Tree Fruit Research Laboratory, Wenatchee, WA 98801

Roger Stanley

HortResearch, Mt. Albert Research Center, Auckland, New Zealand

Conrad Perera

National University of Singapore, 3 Science Drive, Singapore

Jeffrey K. Brecht

Horticultural Sciences Department, University of Florida, Gainesville, FL 32611

\begin{abstract}
Additional Index words. Malus sylvestris (L.) Mill var. domestica (Borkh.) Mansf., electronic nose, aroma volatiles, ethylene, respiration, acidity, firmness, sensory

Aвstract. 'Gala' apples [Malus silvestris (L.) var. domestica (Borkh.) Mansf.] were treated with ethanol vapor $\left(5 \mathrm{~mL} \cdot \mathrm{kg}^{-1}\right.$ fruit for 24 hours at $25^{\circ} \mathrm{C}$ ), heat $\left(4\right.$ days at $38{ }^{\circ} \mathrm{C}$ and $\left.>98 \% \mathrm{RH}\right)$, or 1 -methylcyclopropene $\left(1-\mathrm{MCP} ; 1\right.$ or $0.625 \mu \mathrm{L} \cdot \mathrm{L}^{-1}$ for 18 hours at $20^{\circ} \mathrm{C}$ ) before processing into slices, then dipped in anti-browning solutions or coatings, drained, and packaged in perforated polyethylene bags. Residual effects of pretreatments on fresh-cut slice physiological and quality attributes were investigated during storage for up to 19 days at $5.5^{\circ} \mathrm{C}$. Ethylene production was reduced by ethanol, heat, and 1-MCP pretreatments, while ethanol and heat also reduced slice respiration. Heat and 1-MCP pretreatments inhibited slice texture changes, while ethanol had no effect on instrumental texture measurements but reduced sensory firmness. Ethanol pretreatment increased the contents of ethanol and ethyl esters in slices but reduced acidity, while heat reduced both acidity and aroma volatile levels. Both ethanol and heat pretreatments led to lower sensory scores for apple flavor and ethanol-pretreated slices also received higher scores for altered flavor, although all scores were in the acceptable range. Slice acidity was best maintained by 1-MCP pretreatment. Shelf life based on appearance was 15 to 16 days for ethanol-pretreated slices and 12 days for heat-pretreated slices compared to that of control, which was 8 to 9 days, while 1-MCP pretreatment promoted decay development on the cut surface, which reduced the shelf life to 7 to 8 days. Obvious separations were determined between ethanol- and heat-pretreated slices and untreated control by canonical discriminant analysis of headspace volatile levels determined by GC and electronic nose. Therefore, pretreatments with ethanol and heat are very effective for prolonging visual shelf life at the expense of aroma quality.
\end{abstract}

Much research has been conducted in the last decade on processing and storage of fresh-cut fruit and vegetables. One goal is to help the industry to increase sales of fresh-cut fruit products. Fresh-cut fruit usually have a much larger cut surface, more surface water activity, and a shorter shelf life than fresh-cut vegetables, which have enjoyed billions of dollars in annual sales in the United States (Garrett, 2002). Various approaches have been tried to reduce microbial growth, discoloration, and other deteriorative events. Such approaches include surface treatments

Received for publication4Mar. 2003.Accepted for publication 7Feb. 2004. Mention of a trademark or proprietary product is for identification only and does not imply a guarantee or warranty of the product by the U.S. Dept. of Agriculture. The U.S. Dept. of Agriculture prohibits discrimination in all its programs and activities on the basis of race, color, national origin, gender, religion, age, disability, political beliefs, sexual orientation, and marital or family status.

1To whom reprint requests should be addressed; e-mail ebaldwin@citrus.usda.gov. with coatings or solutions (Bai and Baldwin, 2002; Baldwin et al., 1996; Saftner et al., 2003a), use of modified atmosphere (MA) packaging to maintain high relative humidity $(\mathrm{RH})$ and appropriate gas atmospheres around the cut fruit (Bai et al., 2001; O'Bieme, 1990), low temperature storage, and other special treatments, such as methyl jasmonate, ethanol, and isopropanol vapors (Wang and Buta, 2003).

An alternative method would be to treat the intact fruit before cutting. This might be easily adaptable for industry if the methods, which have been shown to improve intact fruit quality and shelf life, provide a residual influence on the subsequent cut products. It is generally easier to treat intact fruits than processed products due to the stricter sanitation requirements once the peel barrier has been broken.

Application of ethanol vapor at various maturity stages inhibited tomato fruit ripening (Kelly and Saltveit, 1988; Saltveit and Mencarelli, 1988) without affecting subsequent quality (Saltveit 
Table 1. Treatment condition of whole fruit before cutting for three experiments.

\begin{tabular}{|c|c|c|c|c|}
\hline $\begin{array}{l}\text { Expt. } \\
\text { (year) }\end{array}$ & 1-MCP & Heat & Ethanol & Control \\
\hline $\mathrm{I}(2000)$ & $\begin{array}{c}0 \mathrm{~d} \rightarrow 18 \mathrm{~h}\left(1 \mu \mathrm{L} \cdot \mathrm{L}^{-1} 1-\mathrm{MCP}\right. \\
\left.20^{\circ} \mathrm{C}\right) \rightarrow 6.25 \mathrm{~d}\left(3^{\circ} \mathrm{C}\right)^{\mathrm{z}}\end{array}$ & $\begin{array}{l}1 \mathrm{~d}\left(1^{\circ} \mathrm{C}\right) \rightarrow 4 \mathrm{~d} \\
\left(38^{\circ} \mathrm{C}\right) \rightarrow 2 \mathrm{~d}\left(3^{\circ} \mathrm{C}\right)\end{array}$ & $\begin{array}{l}1 \mathrm{~d}\left({ }^{\circ} \mathrm{C}\right) \rightarrow 1 \mathrm{~d}(\text { ethanol } \\
\left.5 \mathrm{~mL} \cdot \mathrm{kg}^{-1} \text { fruit, } 38^{\circ} \mathrm{C}\right) \rightarrow 5 \mathrm{~d}\left(3^{\circ} \mathrm{C}\right)\end{array}$ & $\begin{array}{l}1 \mathrm{~d}\left(1^{\circ} \mathrm{C}\right) \rightarrow \\
6 \mathrm{~d}\left(3^{\circ} \mathrm{C}\right)\end{array}$ \\
\hline II (2001) & $\begin{array}{l}0 \mathrm{~d} \rightarrow 18 \mathrm{~h}\left(0.625 \mu \mathrm{L} \cdot \mathrm{L}^{-1}\right. \\
\left.1-\mathrm{MCP}, 20{ }^{\circ} \mathrm{C}\right) \rightarrow 6.25 \mathrm{~d}\left(1{ }^{\circ} \mathrm{C}\right)\end{array}$ & $\begin{array}{l}1 \mathrm{~d}\left(1^{\circ} \mathrm{C}\right) \rightarrow 4 \mathrm{~d} \\
\quad\left(38^{\circ} \mathrm{C}\right) \rightarrow 2 \mathrm{~d}\left(1^{\circ} \mathrm{C}\right)\end{array}$ & $\begin{array}{l}1 \mathrm{~d}\left(1^{\circ} \mathrm{C}\right) \rightarrow 1 \mathrm{~d}(\text { ethanol } \\
\left.5 \mathrm{~mL} \cdot \mathrm{kg}^{-1} \text { fruit, } 38^{\circ} \mathrm{C}\right) \rightarrow 5 \mathrm{~d}\left(1^{\circ} \mathrm{C}\right)\end{array}$ & $7 d\left(1{ }^{\circ} \mathrm{C}\right)$ \\
\hline III (2001) & $\begin{array}{l}0 \mathrm{~d} \rightarrow 18 \mathrm{~h}\left(0.625 \mu \mathrm{L} \cdot \mathrm{L}^{-1}\right. \\
\left.1-\mathrm{MCP}, 20^{\circ} \mathrm{C}\right) \rightarrow 38.25 \mathrm{~d}\left(1^{\circ} \mathrm{C}\right)\end{array}$ & $\begin{aligned} 1 \mathrm{~d}\left(1^{\circ} \mathrm{C}\right) & \rightarrow 4 \mathrm{~d} \\
\left(38^{\circ} \mathrm{C}\right) & \rightarrow 34 \mathrm{~d}\left(3^{\circ} \mathrm{C}\right)\end{aligned}$ & $\begin{array}{l}1 \mathrm{~d}\left(1^{\circ} \mathrm{C}\right) \rightarrow 1 \mathrm{~d}(\text { ethanol } \\
\left.5 \mathrm{~mL} \cdot \mathrm{kg}^{-1} \text { fruit, } 38^{\circ} \mathrm{C}\right) \rightarrow 37 \mathrm{~d}\left(1^{\circ} \mathrm{C}\right)\end{array}$ & $39 \mathrm{~d}\left(1^{\circ} \mathrm{C}\right)$ \\
\hline
\end{tabular}

${ }^{2}$ Days before pretreatment, in pretreatment, and postpretreatment before cutting of whole fruit.

and Sharaf, 1992). For apple, ethanol vapor was used to reduce superficial scald, a postharvest physiological disorder mainly in Granny Smith apples (Chervin et al., 2001; Ghahramani and Scott, 1998; Scott et al., 1995) by inhibiting $\alpha$-farnesene production and oxidation (Ghahramani and Scott, 1998). Apple is a climacteric-type fruit, and sensitive to ethylene. Wound ethylene, induced by cutting, would accelerate the deterioration of the cut products. Therefore, ethanol vapor pretreatment, as an effective method of ethylene inhibition, was considered a good candidate for an intact fruit treatment.

Heat has been used as a means to control surface microbes, as an insect disinfestation treatment, to delay ripening, and to alleviate pathological disorders for fruits and vegetables (Conway et al., 1994; Lurie, 1998; Lurie and Klein, 1992a; Lurie and Nussinovich, 1996). Ethylene synthesis by apple and tomato fruits was inhibited by heat treatment (Atta Aly, 1992; Biggs et al., 1988; Klein, 1989). Furthermore, fruit treated with heat did not respond to exogenous ethylene (Seymour et al., 1987; Yang et al., 1990). The softening of plum (Tsuji et al., 1984), pear (Maxie et al., 1974), avocado (Eaks, 1978), tomato (Biggs et al., 1988), and apple (Conway et al., 1994; Porritt and Lidster, 1978) was delayed by heating at 30 to $40{ }^{\circ} \mathrm{C}$. A disadvantage of heat treatment is marked loss of volatiles; however, in apple fruit, volatile levels were recovered after an extended refrigerated storage (Fallik et al., 1997).

1-Methylcyclopropene (1-MCP) is an ethylene action inhibitor that reportedly binds to the cellular ethylene receptors and effectively inhibits ethylene responses in plants. 1-MCP inhibits ripening and senescence of many climacteric fruits such as apple (Baritelle et al., 2001; Fan and Mattheis, 1999; Rupasinghe et al., 2000; Saftner et al., 2003b; Watkins et al., 2000), apricot (Fan et al., 2000), banana (Golding et al., 1998; Sisler and Serek, 1997), pear (Baritelle et al., 2001; Lelievre et al., 1997), plum (Abdi et al., 1998), and tomato (Nakatsuka et al., 1997; Sisler and Serek, 1997). A potential disadvantage is that 1-MCP might adversely affect disease resistance (Bent et al., 1992; Ku et al., 1999; Porat et al., 1999) and ethylene-associated flavor volatile production (Rupasinghe et al., 2000). Since 1-MCPhas been recently approved by the Environmental Protection Agency (2002) for postharvest use on apples, it is likely to be used commercially in the near future. 1-MCP has been shown to be beneficial for intact fruit, but its potential for fresh-cut products has not been explored.

In this research, we investigated the residual influence of three pretreatments (ethanol vapor, heat, and 1-MCP) for intact fruit on the subsequent fresh-cut product quality and shelf life.

\section{Materials and Methods}

'Gala' apples were harvested from a commercial orchard located in Wenatchee, Wash., in early Sept. 2000 and 2001, at the preclimacteric stage based on internal ethylene concentrations of
$1.97 \pm 1.38$ (2000) and $0.96 \pm 0.47 \mu \mathrm{L} \cdot \mathrm{L}^{-1}$ (2002) (Watada and Massey, 1981). Defect-free fruit were randomly divided into four batches representing four treatments. Each batch had 30 fruit (Expt. I) for 2000, and 60 fruit (Expts. II and III) for 2001. The batch for 1-MCP pretreatment was immediately treated at USDA Tree Fruit Research Laboratory in Wenatchee, Wash., while other batches were stored in regular air at $1{ }^{\circ} \mathrm{C}$. All fruit were shipped by refrigerated truck the next day to the USDA Citrus and Subtropical Products Laboratory in Winter Haven, Fla., with separate boxes for the 1-MCP-treated fruit. Fruit were then kept in regular air at $3{ }^{\circ} \mathrm{C}(2000)$ or $1{ }^{\circ} \mathrm{C}$ (2001), except during pretreatments, until processed (Table 1).

1-MCP pretreatment was performed by exposing fruit to initial concentrations of 1 (2000) or $0.625 \mu \mathrm{L} \cdot \mathrm{L}^{-1}$ (2001) 1-MCP (EthylBloc, Floralife, Waltersboro, S.C.) at $20{ }^{\circ} \mathrm{C}$ for $18 \mathrm{~h}$. The concentration of 1-MCP was analyzed using a gas chromatograph (GC) (HP 5880A; Hewlett Packard, Avondale, Pa.) fitted with an 80/100 mesh Parapak Q column $(30 \mathrm{~cm} \times 3.2 \mathrm{~mm})$ and a flame ionization detector. The calibration gas was 1-butene (Gong et al., 2002). These levels were determined to be effective for intact apples and the maximum allowed by the U.S. Environmental Protection Agency (EPA) is $1 \mu \mathrm{L} \cdot \mathrm{L}^{-1}$ (EPA, 2002).

Ethanol vapor pretreatment was applied by incubating fruit in a 30-L glass cylinder, sealed at the top and bottom with glass plates for $24 \mathrm{~h}$ at $25^{\circ} \mathrm{C}$. Five milliliters ethanol per kilogram of fruit was placed in an open beaker at the bottom of the jar. A strip of Whatman filter paper was extended within a perforated PVC pipe for the length of the glass cylinder with one end submerged in the beaker of ethanol to help diffuse the vapor throughout the enclosed container.

Heat pretreatment was accomplished by placing fruit at $38^{\circ} \mathrm{C}$ with $>98 \%$ RH for $4 \mathrm{~d}$ (Conway et al., 1994), using a controlled RH chamber (Blue M, Blue Island, Ill.). This would be considered a vapor heat treatment as opposed to other forms of heat treatments such as hot-water dip and hot air (Lurie, 1998).

Since the pretreatment of intact fruit was carried out in different places and took different times for each pretreatment, the subsequent processing of apples into slices was performed $7 \mathrm{~d}$ after harvest for Expt. I (2000) and Expt. II (2001) (Table 1). For Expt. III (2001), pretreatments were carried out at same time as Expt. II; however, the intact fruit were kept $32 \mathrm{~d}$ longer at $1{ }^{\circ} \mathrm{C}$ after pretreatment before processing into slices (and so, fruit were processed $39 \mathrm{~d}$ after harvest, Table 1) to determine if storage after pretreatment would minimize the pretreatment effect on the cut slices.

Processing of fruit into slices was carried out at $5.5{ }^{\circ} \mathrm{C}$ in a clean room where the processing area, tools, and gloved hands were cleaned by $70 \%$ ethanol. Apples (30) in each treatment were separated into three groups representing three replications. Each replicate of 10 apples was washed with $200 \mu \mathrm{L} \cdot \mathrm{L}^{-1}$ hypochlorous acid ( $\mathrm{ClO}$ supplied as sodium hypochlorite at $\mathrm{pH}$ 6.5) solution for $2 \mathrm{~min}$, drained for $\approx 10 \mathrm{~min}$, and hand-cut to 8 to 12 wedges with a 
sharp stainless steel knife. After removal of the seed cavity, the slices, 20 to $25 \mathrm{~g}$ each, were placed into colanders and immediately dipped for $30 \mathrm{~s}$ in a soybean oil emulsion (Expt. I, year 2000 ) containing $0.8 \%$ isoascorbate, $0.8 \%$ calcium propionate, $0.4 \%$ acetylcysteine, $0.02 \%$ 4-hexyl resorcinol, $16.8 \%$ soybean oil (The Hain Food Group, Uniondale, N.Y.), 4.9\% polyoxyethylenesorbitan monostearate (Tween 60; Sigma Chemical Co, St. Louis), and 3.6\% sorbitan monostearate (Uniqema, Wilmington, Del.), all balanced with water. In 2001, a simplified aqueous dipping solution containing $0.8 \%$ isoascorbate, $0.8 \%$ calcium propionate, and $0.4 \%$ acetylcysteine was used because it had been found to be equally effective for retarding browning and maintaining firmness as the soybean oil emulsion used in Expt. I, when compared in another study (Bai and Baldwin, 2002). The slices were then allowed to drain for $1 \mathrm{~h}$ at $5.5^{\circ} \mathrm{C}$ before placement into nine perforated polyethylene bags $(20 \times 18 \mathrm{~cm}$, thickness $30 \mu \mathrm{m}$, with ten $1.5-\mathrm{mm}$ holes), 10 slices per bag, and stored at $5.5^{\circ} \mathrm{C}$ for up to $20 \mathrm{~d}$. The headspace gas in the bags was monitored and $\mathrm{CO}_{2}$ and $\mathrm{O}_{2}$ partial pressures were similar to ambient atmosphere.

A subsample (one out of nine bags per replication) was observed daily for visual quality up to $19 \mathrm{~d}$; six out of the nine bags were prepared for instrumental measurements and panel tests on day 0,7 , and 14 of storage (two bags for each sampling day); two out of the nine bags were prepared for some instrumental attributes at day 3 and 10. Three replicates were performed for all three experiments.

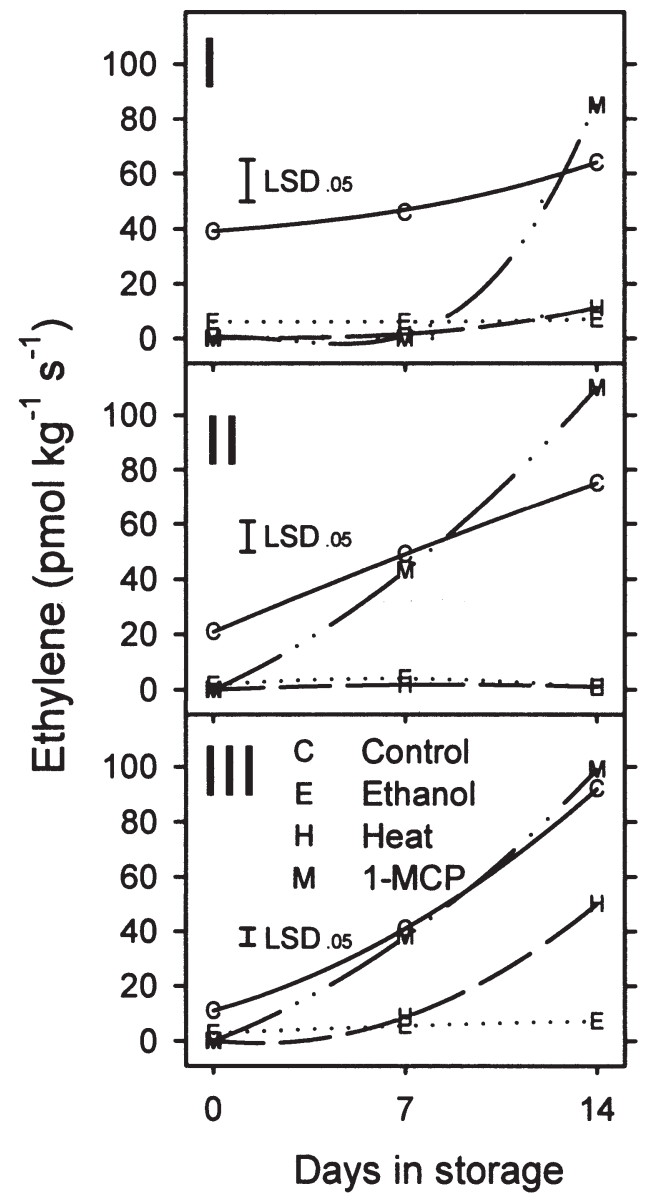

Fig. 1. Changes of ethylene evolution of fresh-cut apple during storage at $5.5^{\circ} \mathrm{C}$ over three experiments (I, II, III) $(\mathrm{n}=3)$. The fruit were pretreated by ethanol vapor, heat, 1-MCP or left untreated before cutting.
Sensory analysis was carried out by an experienced panel of 15 members using a hedonic scale. Randomly coded samples were scored for visual quality, firmness, acidity, sweetness, apple-like flavor, altered flavor, and preference using a 9-point scale with anchor points ( $1=$ low intensity or preference; $9=$ high intensity or preference) at each end. For visual quality scales, a score of 5 (out of 10) is generally considered in postharvest studies to be the threshold level of acceptability. Obvious color change on cut surface and/or any visual microbial colony was evaluated as unacceptable. Altered flavor was interpreted as different from typical apple flavor, but not necessarily off-flavor. A score of 5 for preference or altered flavor was considered to be the threshold level for acceptability, with lower than 5 for preference and higher than 5 of altered flavor being considered unacceptable. The fruit treated by 1-MCP were not sampled by the panelists because the compound had not yet received EPA approval at the time of this experiment.

For respiration and ethylene production rates, 10 apple slices were removed from a bag to a 1-L sealed glass jar, and incubated for $30 \mathrm{~min}$. Well-mixed headspace gas samples were obtained from the jar, and analyzed by GC (model HP 5890; HewlettPackard, Avondale, Pa.). The GC column was a CTR 1 (Alltech Associates, Deerfield, Ill.) with a thermal conductivity detector for $\mathrm{O}_{2}$ and $\mathrm{CO}_{2}$, and an activated alumina column with a flame ionization detector for ethylene.

Color of the cut surface was based on CIE L*, a*, b* and hue angle $\left(\mathrm{H}_{\mathrm{ab}}\right)$ values using a white tile calibrated chromameter (model

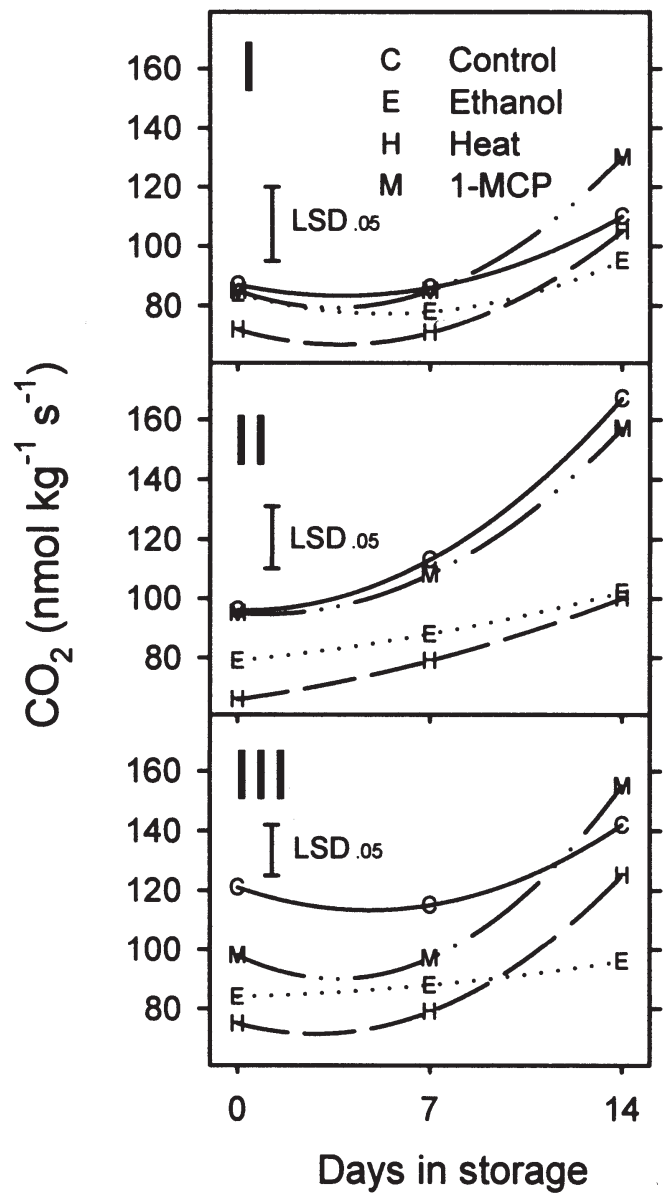

Fig. 2. Changes of respiration rate of fresh-cut apple during storage at $5.5^{\circ} \mathrm{C}$ over three experiments (I, II, III) $(\mathrm{n}=3)$. The fruit were pretreated by ethanol vapor, heat, 1-MCP or left untreated before cutting. 
CR-300; Minolta, Tokyo) with five slices per replication.

Firmness was determined using a texture analyzer (model XT2i; Stable Micro Systems, Godalming, U.K.), calibrated with a 5-kg weight and equipped with a 3 -mm-diameter probe. A 10-mm-thick piece was obtained from the equatorial part of the wedge. The insert distance was $5.0 \mathrm{~mm}$, with a stroke speed of $5.0 \mathrm{~mm} \cdot \mathrm{s}^{-1}$. Four slices were measured per replicate bag, and the firmness was expressed in Newtons $(\mathrm{N})$.

For headspace GC volatile and electronic nose analysis, 50-g apple slices were homogenized with $25 \mathrm{~mL}$ deionized water and 25 $\mathrm{mL}$ saturated $\mathrm{NaCl}$ solution. The homogenate were transferred to glass vials sealed with a crimp-topped Teflon-silicone septum, flash frozen in liquid nitrogen and stored at $-80^{\circ} \mathrm{C}$ before analysis. The sample prepared for headspace volatile analysis by $\mathrm{GC}$ consisted of $2 \mathrm{~mL}$ of homogenate in a 6-mL vial, and that for electronic nose consisted of $3 \mathrm{~mL}$ in a $10-\mathrm{mL}$ vial. Sample vials were thawed under running tap water immediately before analysis.

For headspace $\mathrm{GC}$ analysis, sample vials were incubated at $80^{\circ} \mathrm{C}$ for 15 min by a heating block in a headspace sampler (HS-6; Perkin Elmer, Norwalk, Conn.) before the headspace sample was injected into the GC. The analysis was carried out using a gas chromatograph (model 8500, Perkin Elmer) equipped with a $0.53 \mathrm{~mm} \times 30 \mathrm{~m}$ polar Stabilwax capillary column (1.0-Fm film thickness; Restek, Bellefonte, $\mathrm{Pa}$.) and a flame ionization detector. Oven temperature was held $40^{\circ} \mathrm{C}$ for $6 \mathrm{~min}$, then raised to $180^{\circ} \mathrm{C}$ at a rate of $6{ }^{\circ} \mathrm{C} /$ $\mathrm{min}$. The compounds were identified by comparison of retention times with those of authenticated standards and by enrichment of

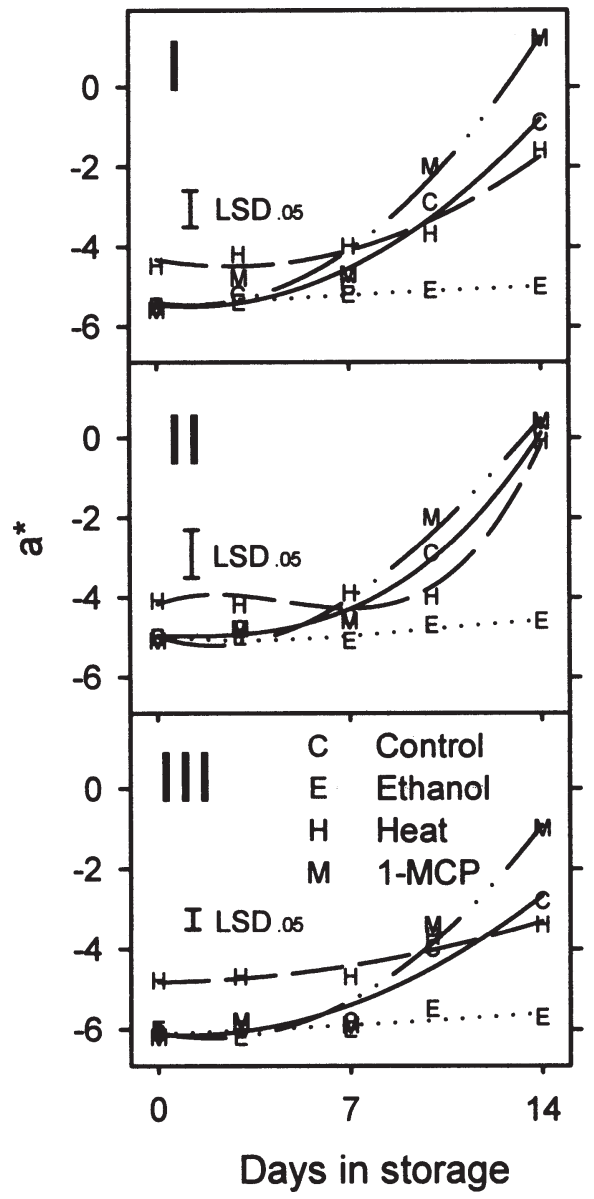

Fig. 3. Changes of CIE a* value on cut surface of fresh-cut apple during storage at $5.5^{\circ} \mathrm{C}$ over three experiments (I, II, III) $(\mathrm{n}=3)$. The fruit were pretreated by ethanol vapor, heat, 1-MCP or left untreated before cutting. apple homogenate with authentic compounds. Concentrations were calculated by using regression equations, obtained by five different concentrations of each standard (Bai et al., 2002).

For electronic nose analysis, a Fox 4000 system (Alpha MOS, Toulouse, France) was used, fitted with 18 metal-oxide sensors, some with coated surfaces. The electrical output from the sensors was measured at 0.5 -s intervals. Samples were incubated in an agitator at $500 \mathrm{rpm}$ and $40{ }^{\circ} \mathrm{C}$ for $2 \mathrm{~min}$ before the headspace sample $(500 \mu \mathrm{L})$ was taken from the vial and injected into the electronic nose. The carrier gas was pure air with a flow rate of $150 \mathrm{~mL} \cdot \mathrm{min}^{-1}$. The electronic nose data acquisition program was a 2-min sampling time followed by an 18-min delay between samples for sensor recovery.

SAS version 8 (SAS Institute, Cary, N.C.) was used for analysis of data (SAS Institute, 1999). Sensory, cut surface color, firmness, respiration rate, ethylene production, and volatile concentrations were analyzed using the analysis of variance (PROCANOVA), mean separation was determined by the Duncan's multiple range test for each experiment. Electronic nose and headspace GC volatile data were analyzed using the canonical discriminant analysis (PROC CANDISC) for the three experiments combined.

\section{Results and Discussion}

In general, heat and ethanol pretreatments inhibited slice ethylene production (Fig. 1), respiration (Fig. 2) and discoloration [lower a* values (Fig. 3) and higher L* values (Fig. 4)] during 2 weeks

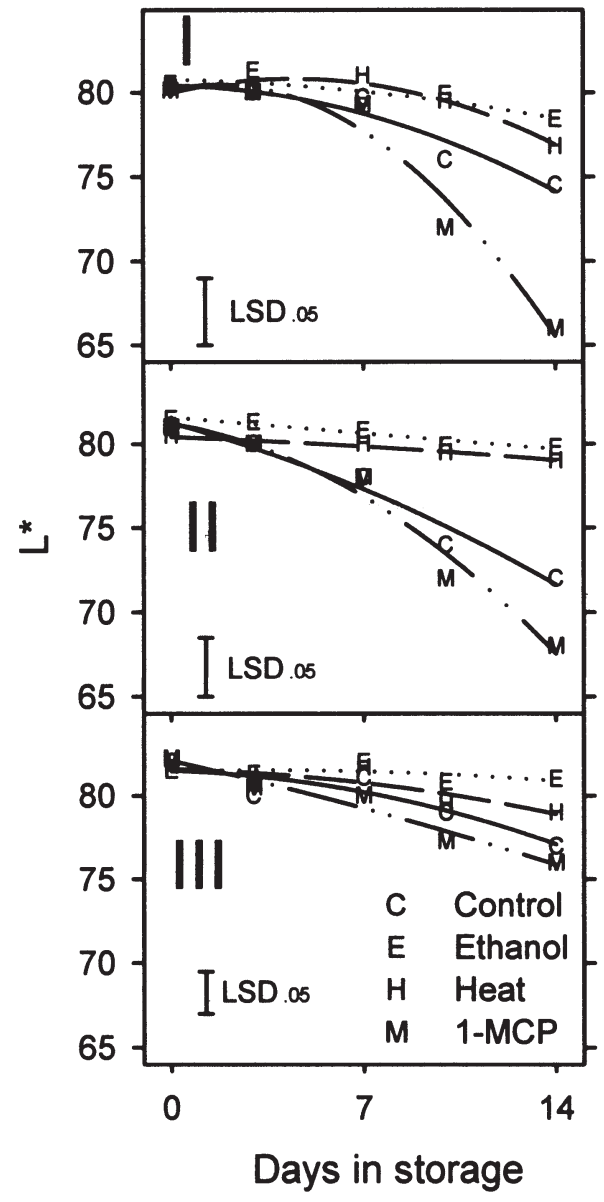

Fig. 4. Changes of CIE L* value on cut surface of fresh-cut apple during storage at $5.5^{\circ} \mathrm{C}$ over three experiments $(\mathrm{I}, \mathrm{II}, \mathrm{III})(\mathrm{n}=3)$. The fruit were pretreated by ethanol vapor, heat, 1-MCP or left untreated before cutting. 
of storage compared to nonpretreated control slices and 1-MCP pretreated slices. Titratable acidity and firmness generally declined during storage (Figs. 5 and 6), especially in nonpretreated control fruit and there were differences between treatments as denoted by LSD on figures. Initial acidity levels, however, were lower in ethanol and heat pretreated slices, and heat pretreated slices exhibited the lowest acidity during 2 weeks of storage. Nonpretreated control slices were generally less firm than pretreated slices, and 1-MCPtreated slices tended to be more firm, especially in Expt. III.

ETHYLENE. All of the pretreatments decreased ethylene evolution by cut slices to some extent (Fig. 1). The initial ethylene evolution immediately after cutting was low to undetectable in 1-MCP pretreated slices, however, ethylene synthesis increased sharply during storage, reaching control levels by day 7 for Expts. II and III and day 14 for Expt. I. 1-MCP has been reported to extend the shelf life of apple and many other climacteric fruits by inhibiting ethylene synthesis and action (Baritelle et al., 2001; Fan and Mattheis, 1999; Golding et al., 1998; Rupasinghe et al., 2000; Saftner et al., 2003b; Sisler and Serek, 1997). Heat-pretreated slices, however, also had very low ethylene evolution immediately after cutting (undetectable in Expts. I and II, and $\approx 1 \mathrm{pmol} \cdot \mathrm{kg}^{-1} \cdot \mathrm{s}^{-1}$ in Expt. III), which remained low throughout storage for Expts. I and II, but increased by day 14 in Expt. III, where the intact fruit were stored after pretreatment and before cutting for $32 \mathrm{~d}$ (Fig. 1). Apparently, the slices recovered some ability to produce ethylene in this case.

The mechanisms of heat inhibition of ethylene production are reportedly due to the heat sensitivity of ACC oxidase (Chan, 1986;

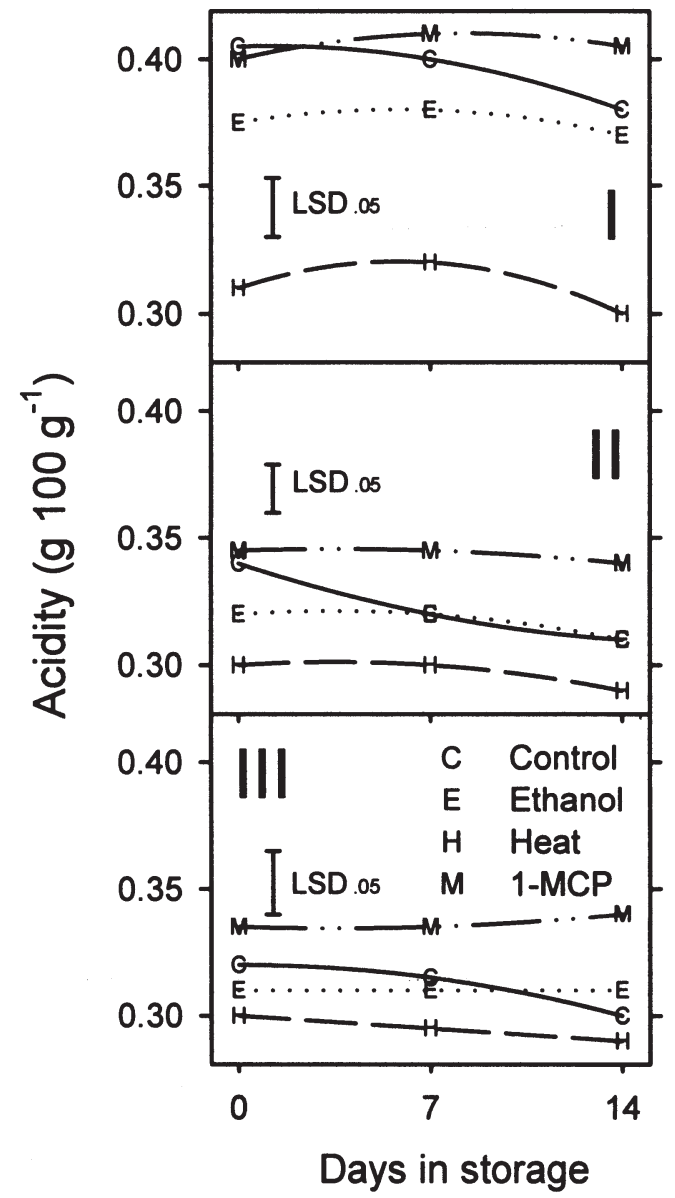

Fig. 5. Changes of titratable acidity content of fresh-cut apple during storage at $5.5^{\circ} \mathrm{C}$ over three experiments (I, II, III) $(\mathrm{n}=3)$. The fruit were pretreated by ethanol vapor, heat, 1-MCP or left untreated before cutting.
Paull and Chen, 1990) and ACC synthase (Biggs et al., 1988). ACC oxidase synthesis and mRNA also decreased due to heat treatment (Lurie et al., 1996). The inhibition of ethylene formation was reversed when the fruit are removed from heat (Biggs et al., 1988; Chan, 1991; Dunlap et al., 1990). In this study, the intact fruit used in Expt. III were removed from heat pretreatment and stored for 32 $\mathrm{d}$ at $1^{\circ} \mathrm{C}$ before processing (Table 1 ), therefore, ethylene evolution of the subsequent cut slices was higher than in Expts. I and II by day 14 (Fig. 1). Lurie and Klein (1992b) reported that the level of ethylene evolution from heat-treated apples could rise to higher levels than in nonheated fruit, given enough recovery time after removal from heat.

Ethanol pretreatment inhibited ethylene production to $<20 \%$ of control levels during $14 \mathrm{~d}$ of storage at $5.5^{\circ} \mathrm{C}$ (Fig. 1). Previous reports maintained that ethanol vapor pretreatment inhibited ethylene synthesis and action in tomato (Saltveit and Mencarelli, 1988; Yanuriati et al., 1999), although it could promote ethylene production at low concentrations (Beaulieu and Saltveit, 1997). A possible mechanism proposed by Beaulieu and Saltveit (1997) is that endogenous concentration of acetaldehyde is the biologically active factor that affects ethylene production, such that if high concentrations and/or long doses of ethanol are applied, there is a conversion of the excess ethanol to acetaldehyde. Ripening is then inhibited due to a reduction in activity of ACC oxidase. Conversely, if less-than-inhibitory concentrations of ethanol are applied, it appears to induce the synthesis of ACC (Mencarelli et al., 1991), or increase ACC synthase activity.

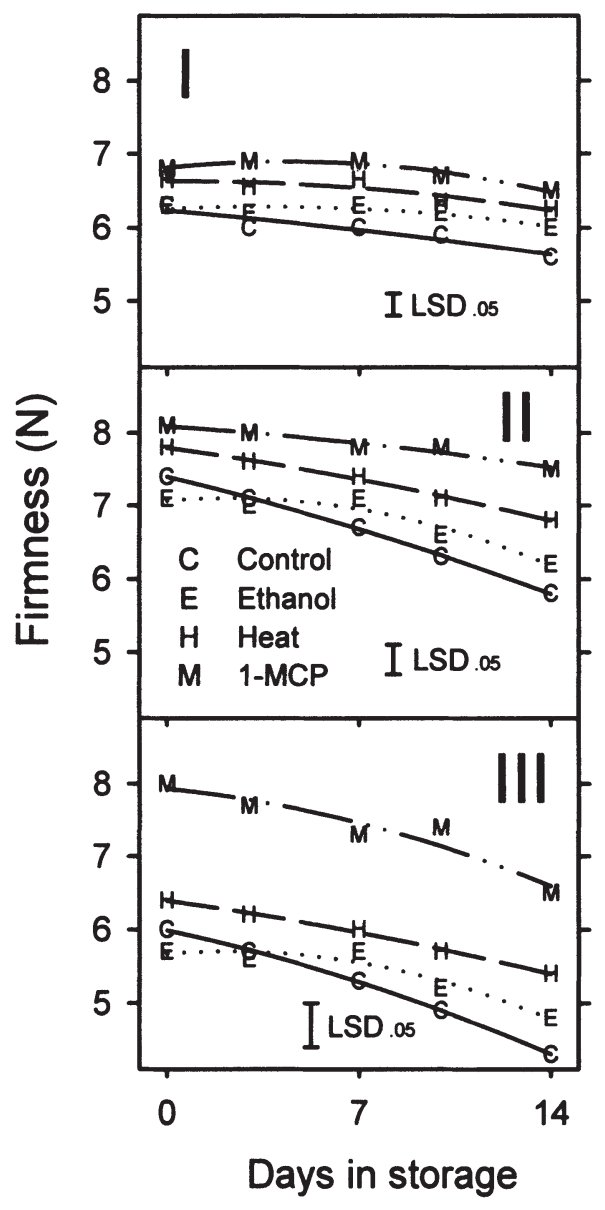

Fig. 6. Changes of flesh firmness of fresh-cut apple during storage at $5.5^{\circ} \mathrm{C}$ over three experiments (I, II, III) $(\mathrm{n}=3)$. The fruit were pretreated by ethanol vapor, heat, 1-MCP or left untreated before cutting. 


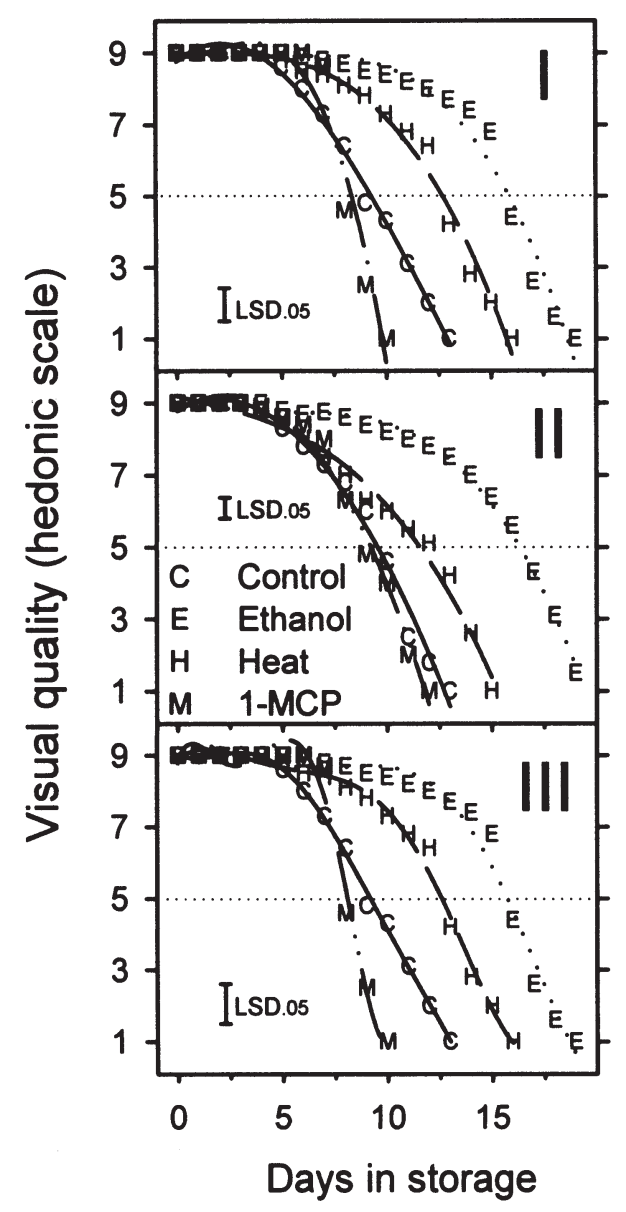

Fig. 7. Changes of visual quality of fresh-cut apples kept at $5.5^{\circ} \mathrm{C}$ for $19 \mathrm{~d}$ over three experiments (I, II, III). The fruit were pretreated by ethanol vapor, heat, 1-MCP, or left untreated before cutting.

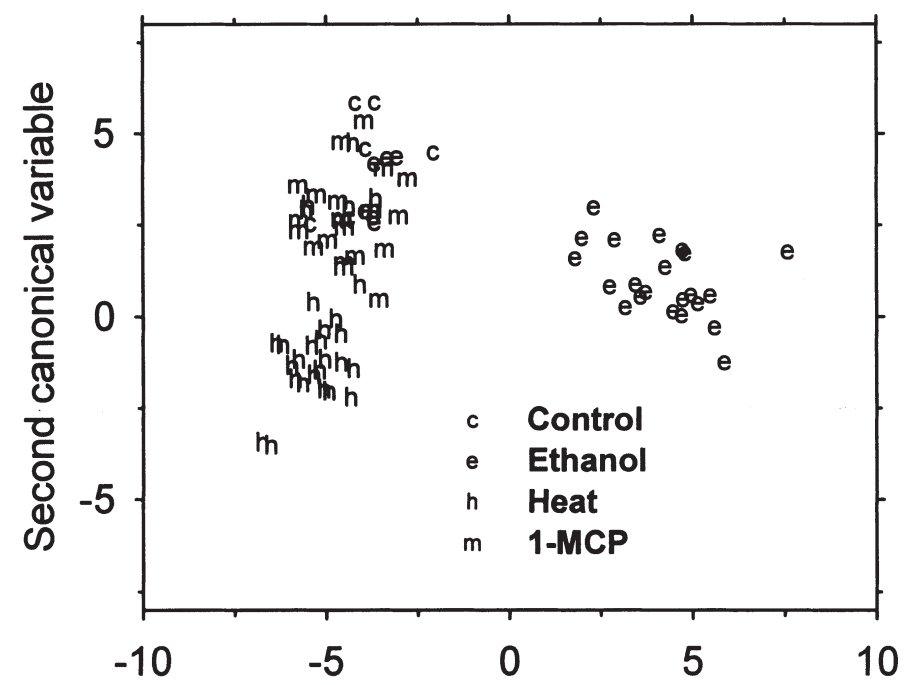

First canonical variable

Fig. 8. Canonical discriminant analysis of headspace GC volatile concentration in fresh-cut apple. The fruit were pretreated by ethanol vapor, heat, 1-MCP or left untreated (control) before cutting, and were represented in the figure as e, $\mathrm{h}, \mathrm{m}$ and $\mathrm{c}$, respectively $[\mathrm{n}=3$ experiments $\times 3$ to 6 replications $\times 2$ storage times $\left(0\right.$ and $7 \mathrm{~d}$ at $\left.\left.5.5^{\circ} \mathrm{C}\right)\right]$
RESPIRATION. Respiration rates (Fig. 2) were significantly decreased by ethanol and heat pretreatments throughout the storage period. However, 1-MCP pretreatments generally did not significantly affect respiration rate (Fig. 2). Since 1-MCP has been reported to inhibit respiration rate in whole apple (Fan et al., 1999; Saftner et al., 2003b), a possible reason for the high respiration rate observed in the cut fruit could be due to the wound response. Wound-induced respiration, as opposed to ripeninginduced respiration, might somehow circumvent the need for ethylene action or effects of 1-MCP.

APPEARANCE AND SHELF LIFE. The shelf life of ethanol- and heat-pretreated slices were 15 to 16 and $12 \mathrm{~d}$, which was 7 (78\% to $88 \%)$ and 3 to $4 \mathrm{~d}(33-50 \%)$ longer than that of the nonpretreated controls ( 8 to $9 \mathrm{~d}$ ), respectively, based on visual observance (Fig. 7). All slices eventually became unacceptable due to discoloration and gray mold growth on the cut surface. The pretreatment of intact fruit with 1-MCP, however, shortened the shelf life to 7 to $8 \mathrm{~d}$, which was 1 day shorter than controls (Fig. 7), and resulted in more serious discoloration and decay of the cut surface than observed in control slices. This appeared to be due to secondary browning, or discoloration caused by microbial growth. There is concern that decreases in ethylene sensitivity (such as with 1-MCP treatment) might adversely affect plant tissue disease resistance (Bent et al., 1992). Ethylene has been correlated with induction of a wide range of resistance responses, however, pretreatment of apples with ethanol or heat, which inhibited ethylene production, decreased disease incidence and severity compared to $1-\mathrm{MCP}$ treated fruit and controls. Therefore, either only a small amount of ethylene is required to induce disease resistance, or additional factors about the 1-MCP treatment increased decay in the slices. Alternatively, both the heat and ethanol vapor treatments could be considered anti-microbial and may have reduced microbial loads on the fruit surface, which resulted in reduced microbial loads on the surface of the cut slices. This, however, does not explain why 1-MCP-pretreated slices had more decay than controls. Another possibility is that 1-MCP impaired the apple tissue defense system by some mechanism independent

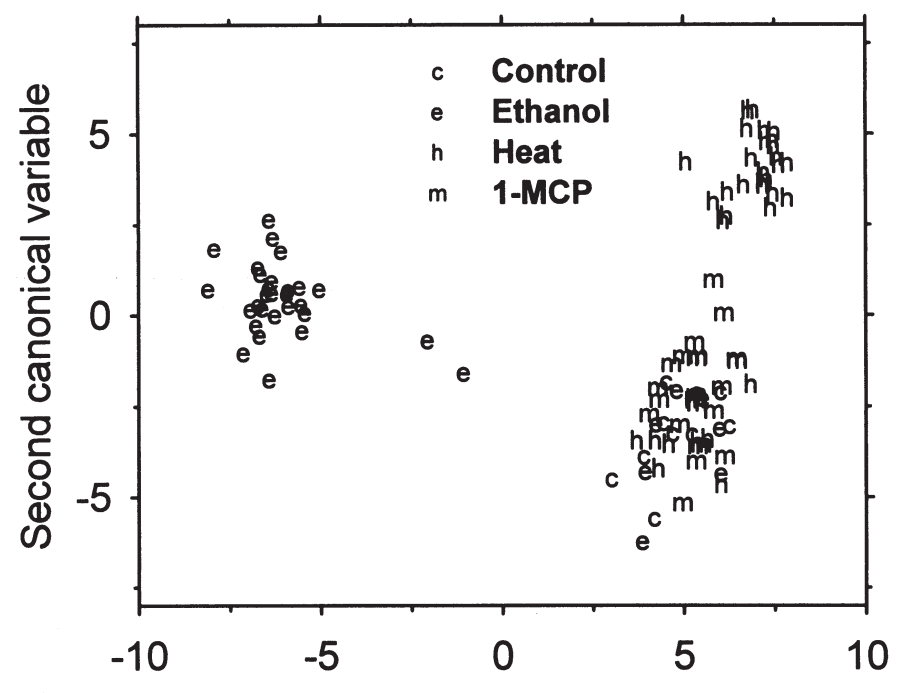

First canonical variable

Fig. 9. Canonical discriminant analysis of electronic nose data of fresh-cut apple. The fruit were pretreated by ethanol vapor, heat, 1-MCP or left untreated (control) before cutting, and were represented in the figure as e, $h, m$, and $c$, respectively $[n=3$ experiments $\times 3$ replicates $\times 2$ storage time $\left(0\right.$ and $7 \mathrm{~d}$ at $\left.\left.5.5^{\circ} \mathrm{C}\right)\right]$. 
of ethylene synthesis and action. Itai et al. (2000) reported that, in Japanese pear, 1-MCP reduced expression of one out of three plant defense-related proteins evaluated. Interestingly, in a separate study in New Zealand with 'Braeburn' and 'Pacific Rose' apples pretreated with 1-MCP and then sliced, the results were similar for reduced ethylene with little effect on respiration (respiration slightly reduced for 'Braeburn' and no difference for 'Pacific Rose'), however, no increased decay susceptibility was observed in these varieties (Perera et al., 2003).

The severity of slice deterioration corresponded with chromameter measurements. Higher $a^{*}$ (green to red) indicates more browning, whereas higher $\mathrm{L}^{*}$ values indicate lighter(whiter) color. No obvious browning occurred, due to the use of antibrowning agents (Bai and Baldwin, 2002), and discoloration was mostly due to mold growth (secondary browning), as 1-MCP pretreated slices lost shelf life after 7 to $8 \mathrm{~d}$ of storage (Fig. 7). Cut surface color did not change much in the first $7 \mathrm{~d}$ but remarkably discolored in the second week of storage with increasing a* (Fig. 3) and decreasing $\mathrm{L}^{*}$ (Fig. 4) values for 1-MCP-pretreated and nonpretreated control slices. However, ethanol- and heat-pretreated slices maintained visual acceptance for 12 to $16 \mathrm{~d}$ (Fig. 7) which was reflected in fairly stable values for a* (ethanol) and L* (heat and ethanol, Figs. 3 and 4, respectively). Ethanol pretreated slices generally showed lower $\mathrm{a}^{*}$ and ethanol and heat pretreated slices showed higher $\mathrm{L}^{*}$ values than 1-MCP pretreated on nonpretreated control slices (Figs. 3 and 4). Meanwhile, 1-MCP-pretreated slices displayed similar or higher $\mathrm{a}^{*}$ and similar or lower $\mathrm{L}^{*}$ compared with untreated controls (Figs. 3 and 4). Slices from heat-pretreated fruit exhibited higher a* (Fig. 3) and lower b* (data not shown) initial values than control slices or slices from the other pretreated fruit, however, no color difference was visually observed. Lurie and Klein (1990) reported a decrease in chlorophyll content in apple peel due to heat treatment, and a similar decrease was supposed to have occurred in the flesh, although the flesh contains much less chlorophyll than that in peel.

Titratable ACIDITy. 1-MCP-pretreated slices and nonpretreated controls exhibited the highest initial levels of titratable acidity, but control slices showed the greatest rate of acidity decline during 2 weeks of storage, while acidity levels were generally maintained in 1-MCP-pretreated slices. Initial levels for titratable acidity were lower for ethanol- and heat-pretreated slices compared to 1-MCP-pretreated and nonpretreated controls (Fig. 5 ). It is possible that the acids were used as respiratory substrate during pretreatment at $25{ }^{\circ} \mathrm{C}$, and/or acids were used in ester synthesis due to metabolism of the excess ethanol, which is an ester precursor. Heat-pretreatment resulted the lowest initial acidity levels in slices compared to all other pretreatments and nonpretreated controls. Both ethanol and heat-treated slices showed a slight decline in acidity levels in the second week of storage (Fig. 5 ). None of the pretreatments had any effect on soluble solids levels in the subsequent slices (data not shown). Similar results were observed by Klein et al. (1990), Liu (1978), and Porritt and Lidster (1978), for heat-treated intact fruit.

Aroma volatiles. Overall, after 1 week of storage, ethanolpretreated slices displayed the highest level of total volatiles, followed by nonpretreated controls and 1-MCP-treated slices (which were similar), with heat-pretreated slices having the lowest total volatile levels (Table 2). This agrees with earlier data published in a review by Beaulieu and Baldwin (2002), where slices dipped in ethanol did not have the same effect (reduced browning) as slices from fruit subjected to ethanol vapor. Ethanol pretreatment led to accumulation of ethanol and some ethyl esters in fruit slices, especially ethyl acetate and ethyl propionate (Table 2). Storage of intact fruit for $32 \mathrm{~d}$ at $1{ }^{\circ} \mathrm{C}$ after heat treatment (Expt. III) did not result in volatile recovery (Table 2). Ethyl acetate, ethyl propionate, and ethyl butanoate increased during the first week of storage for nonpretreated controls, ethanol, heat, and 1$\mathrm{MCP}$-pretreated slices in some cases. For nonpretreated control slices, butyl acetate, 2-methylbutyl acetate, hexyl acetate, butyl butanoate, 2-methylbutyl-3-methylbutanoate, and butanol (seven out of the 12 volatiles measured) generally declined during the first week of storage, while ethyl hexanoate, butyl hexanoate, and ethanol levels generally did not change. For ethanol-pretreated slices, four out of the 12 volatiles measured declined, including hexyl acetate, butyl butanoate, 2-methylbutyl-3-methylbutanoate, and butyl hexanoate as well as ethyl hexanoate and 2-methylbutyl acetate (Expts. I and III). No volatiles declined over 1 week of storage for heat-pretreated fruit (except butyl butanoate and butanol in Expt. I), and in fact many increased. Nevertheless, butyl butanoate and 2-methylbutyl-3-methylbutanoate were only found at trace levels in Expts. I (methylbutanoate only) and II, and volatiles were generally low compared to the other pretreated slices. Many volatiles actually increased in the first week and 1-MCP-pretreated fruit exhibited a similar pattern of volatile trend during the first week of storage as did nonpretreated controls. The mechanism by which heat inhibits apple volatiles, especially the major apple aroma-esters, has not been reported. However, the disappearance of mRNA for fruit ripening genes and the accumulation of heat shock proteins (Lurie et al., 1996; Picton and Grierson, 1988) can affect volatile production. In addition, ethylene has been associated with volatile production in apples (Mattheis et al. 1991), and the heat pretreatment resulted in the lowest ethylene levels of all the pretreatments. This may be the reason that heat-pretreated slices exhibited the lowest volatiles levels as well.

Canonical discriminant analysis of headspace GC volatiles and electronic nose data over three experiments separated the ethanolpretreatment slices from nonpretreated control slices and those from other pretreatments in the first canonical variable (Figs. 8 and 9), which had the most discriminatory power (77\% for GC volatiles and $78 \%$ for electronic nose data). The second canonical variable, representing $22 \%$ of the variation for both GC and nose data, separated nonpretreated control slices from heat-pretreated slices based on GC headspace volatiles (Fig. 8) and electronic nose data (Fig. 9). The squared canonical correlation $\left(R^{2}\right)$ values between first canonical variable and the actual GC and nose data was 0.94 for the headspace $\mathrm{GC}$ volatiles, and 0.97 for the electronic nose data. The squared canonical correlation $\left(R^{2}\right)$ value between second canonical variable the GC and nose data was also high: 0.80 for the headspace $\mathrm{GC}$ volatiles, and 0.89 for the electronic nose data. The square distances between treatments were significant (Table 3). This information indicates that there should be flavor differences between ethanol-pretreated slices and the other pretreated and nonpretreated slices and between the heat-pretreated slices and the 1-MCP and nonpretreated control slices, based on aroma volatile profiles. This was somewhat supported by the sensory data, where apple-like rating was highest in nonpretreated controls and lowest in heat-pretreated slices, while altered flavor was highest in ethanol-pretreated slices (Table 4).

FirMnESS. Instrumental measurement of slice tissue firmness revealed that slices from 1-MCP- and heat-pretreated fruit had higher firmness and softened more slowly over the storage period than nonpretreated controls, and in some cases, ethanol pretreated slices (Fig. 6). The same phenomenon was reported by previous 
Table 2. Concentration of volatile components $\left(\mu \mathrm{mol} \cdot \mathrm{L}^{-1}\right)$ in fresh-cut 'Gala' apples kept at $5.5^{\circ} \mathrm{C}$ for $7 \mathrm{~d}$. Intact fruit were treated with ethanol vapor, heat, 1-MCP, or left untreated before cutting. ${ }^{2}$

\begin{tabular}{|c|c|c|c|c|c|c|c|c|}
\hline \multirow[b]{3}{*}{ Component } & \multicolumn{8}{|c|}{ Pretreatment } \\
\hline & \multicolumn{2}{|c|}{ Control } & \multicolumn{2}{|c|}{ Ethanol } & \multicolumn{2}{|c|}{ Heat } & \multicolumn{2}{|c|}{ 1-MCP } \\
\hline & Day 0 y & Day 7 & Day 0 & Day 7 & Day 0 & Day 7 & $\overline{\text { Day } 0}$ & Day 7 \\
\hline \multicolumn{9}{|l|}{ Expt. I } \\
\hline Ethyl acetate & $0.8 \mathrm{e}^{\mathrm{x}}$ & $77.9 \mathrm{c}$ & $257.4 \mathrm{a}$ & $185.0 \mathrm{~b}$ & $0.4 \mathrm{a}$ & $9.8 \mathrm{~d}$ & $1.8 \mathrm{e}$ & $14.7 \mathrm{~d}$ \\
\hline Ethyl propionate & $42.1 \mathrm{c}$ & $72.1 \mathrm{~b}$ & $250.3 \mathrm{a}$ & $194.4 \mathrm{a}$ & $36.3 \mathrm{c}$ & $44.3 \mathrm{c}$ & $79.5 \mathrm{~b}$ & $63.3 \mathrm{bc}$ \\
\hline Ethyl butanoate & $1.3 \mathrm{c}$ & $12.2 \mathrm{a}$ & $1.5 \mathrm{c}$ & $9.4 \mathrm{a}$ & $1.3 \mathrm{c}$ & $4.0 \mathrm{~b}$ & $1.4 \mathrm{c}$ & $7.1 \mathrm{ab}$ \\
\hline Ethyl hexanoate & $0.08 \mathrm{~b}$ & $0.09 \mathrm{ab}$ & $0.22 \mathrm{a}$ & $0.06 \mathrm{~b}$ & $0.04 \mathrm{~b}$ & $0.07 \mathrm{~b}$ & $0.18 \mathrm{a}$ & $0.01 \mathrm{c}$ \\
\hline Butyl acetate & $21.7 \mathrm{a}$ & $6.4 \mathrm{bc}$ & $9.7 \mathrm{ab}$ & $4.1 \mathrm{c}$ & $0.6 \mathrm{~d}$ & $0.7 \mathrm{~d}$ & $17.0 \mathrm{a}$ & $3.9 \mathrm{c}$ \\
\hline 2-methylbutyl acetate & $8.1 \mathrm{ab}$ & $3.8 \mathrm{c}$ & $15.1 \mathrm{a}$ & $3.5 \mathrm{c}$ & $1.4 \mathrm{~d}$ & $1.0 \mathrm{~d}$ & $5.6 \mathrm{bc}$ & $1.3 \mathrm{~d}$ \\
\hline Hexyl acetate & $1.1 \mathrm{a}$ & $0.2 \mathrm{~b}$ & $0.8 \mathrm{a}$ & $0.1 \mathrm{~b}$ & $0.01 \mathrm{c}$ & $0.01 \mathrm{c}$ & $0.9 \mathrm{a}$ & $0.03 \mathrm{c}$ \\
\hline Butyl butanoate & $0.9 \mathrm{bc}$ & $0.3 \mathrm{~d}$ & $2.6 \mathrm{a}$ & $0.6 \mathrm{c}$ & $1.2 \mathrm{~b}$ & $0.6 \mathrm{c}$ & $1.3 \mathrm{~b}$ & $0.1 \mathrm{~d}$ \\
\hline \multicolumn{9}{|l|}{ 2-methylbutyl } \\
\hline 3-methylbutanoate & $1.0 \mathrm{a}$ & $0.2 \mathrm{~b}$ & $0.7 \mathrm{a}$ & $0.1 \mathrm{~b}$ & $\operatorname{tr}$ & $\operatorname{tr}$ & $0.8 \mathrm{a}$ & $0.1 \mathrm{~b}$ \\
\hline Butyl hexanoate & $0.27 \mathrm{ab}$ & $0.17 \mathrm{c}$ & $0.57 \mathrm{a}$ & $0.22 \mathrm{bc}$ & $0.13 \mathrm{~cd}$ & $0.13 \mathrm{~cd}$ & $0.27 \mathrm{ab}$ & $0.11 \mathrm{~d}$ \\
\hline Ethanol $\left(\times 10^{3}\right)$ & $9.0 \mathrm{c}$ & $11.3 \mathrm{bc}$ & $50.6 \mathrm{a}$ & $49.1 \mathrm{a}$ & $6.9 \mathrm{~d}$ & $10.7 \mathrm{c}$ & $18.6 \mathrm{~b}$ & $11.4 \mathrm{bc}$ \\
\hline Butanol & $24.0 \mathrm{a}$ & $4.5 \mathrm{c}$ & $13.0 \mathrm{~b}$ & $2.3 \mathrm{~d}$ & $5.8 \mathrm{c}$ & $2.1 \mathrm{~d}$ & $46.1 \mathrm{a}$ & $3.9 \mathrm{~cd}$ \\
\hline $\begin{array}{l}\text { Total volatile abundanc } \\
\text { (peak height, } \times 10^{4} \text { ) }\end{array}$ & $5.2 \mathrm{c}$ & $7.0 \mathrm{~b}$ & $24.0 \mathrm{a}$ & $21.4 \mathrm{a}$ & $3.2 \mathrm{c}$ & $5.0 \mathrm{c}$ & $8.6 \mathrm{~b}$ & $6.8 \mathrm{bc}$ \\
\hline \multicolumn{9}{|l|}{ Expt. II } \\
\hline Ethyl acetate & $0.8 \mathrm{c}$ & $17.0 \mathrm{~b}$ & $396.4 \mathrm{a}$ & $763.7 \mathrm{a}$ & $0.5 \mathrm{c}$ & $0.9 \mathrm{c}$ & $1.2 \mathrm{c}$ & $36.2 \mathrm{~b}$ \\
\hline Ethyl propionate & $0.2 \mathrm{e}$ & $0.5 \mathrm{de}$ & $192.3 \mathrm{~b}$ & $289.1 \mathrm{a}$ & $0.7 \mathrm{~d}$ & $2.2 \mathrm{~d}$ & $1.2 \mathrm{~d}$ & $15.9 \mathrm{c}$ \\
\hline Ethyl butanoate & $1.3 \mathrm{~cd}$ & $16.6 \mathrm{a}$ & $1.7 \mathrm{c}$ & $17.1 \mathrm{a}$ & $1.2 \mathrm{~d}$ & $4.3 \mathrm{~b}$ & $1.4 \mathrm{~cd}$ & $10.8 \mathrm{ab}$ \\
\hline Ethyl hexanoate & $0.59 \mathrm{a}$ & $0.67 \mathrm{a}$ & $0.56 \mathrm{a}$ & $0.55 \mathrm{a}$ & $0.21 \mathrm{~b}$ & $0.47 \mathrm{ab}$ & $0.54 \mathrm{ab}$ & $0.43 \mathrm{ab}$ \\
\hline Butyl acetate & $25.5 \mathrm{a}$ & $18.8 \mathrm{ab}$ & $6.8 \mathrm{c}$ & $14.7 \mathrm{~b}$ & $0.1 \mathrm{~d}$ & $0.1 \mathrm{~d}$ & $22.0 \mathrm{a}$ & $15.0 \mathrm{~b}$ \\
\hline 2-methylbutyl acetate & $6.0 \mathrm{ab}$ & $5.6 \mathrm{ab}$ & $8.3 \mathrm{a}$ & $10.7 \mathrm{a}$ & $0.5 \mathrm{c}$ & $1.0 \mathrm{c}$ & $5.1 \mathrm{~b}$ & $3.2 \mathrm{bc}$ \\
\hline Hexyl acetate & $1.61 \mathrm{a}$ & $0.43 \mathrm{~b}$ & $0.58 \mathrm{~b}$ & $0.18 \mathrm{c}$ & $0.04 \mathrm{~d}$ & $0.05 \mathrm{~d}$ & $1.03 \mathrm{ab}$ & $0.17 \mathrm{c}$ \\
\hline Butyl butanoate & $0.86 \mathrm{a}$ & $0.19 \mathrm{~b}$ & $0.86 \mathrm{a}$ & $0.13 \mathrm{~b}$ & $\operatorname{tr}$ & $\operatorname{tr}$ & $0.57 \mathrm{a}$ & $0.02 \mathrm{c}$ \\
\hline \multicolumn{9}{|l|}{ 2-methylbutyl } \\
\hline 3-methylbutanoate & $1.40 \mathrm{a}$ & $0.40 \mathrm{~b}$ & $0.53 \mathrm{~b}$ & $0.19 \mathrm{c}$ & $\operatorname{tr}$ & $\operatorname{tr}$ & $0.91 \mathrm{a}$ & $0.18 \mathrm{c}$ \\
\hline Butyl hexanoate & $0.25 \mathrm{a}$ & $0.16 \mathrm{ab}$ & $0.25 \mathrm{a}$ & $0.15 \mathrm{ab}$ & $0.12 \mathrm{~b}$ & $0.12 \mathrm{~b}$ & $0.21 \mathrm{a}$ & $0.14 \mathrm{~b}$ \\
\hline Ethanol $\left(\times 10^{3}\right)$ & $4.7 \mathrm{~b}$ & $3.9 \mathrm{bc}$ & $54.0 \mathrm{a}$ & $58.4 \mathrm{a}$ & $1.1 \mathrm{~d}$ & $2.4 \mathrm{~cd}$ & $2.4 \mathrm{~cd}$ & $4.8 \mathrm{~b}$ \\
\hline Butanol & $74.8 \mathrm{a}$ & $19.0 \mathrm{~b}$ & $19.4 \mathrm{~b}$ & $23.7 \mathrm{~b}$ & $2.2 \mathrm{c}$ & $2.0 \mathrm{c}$ & $81.7 \mathrm{a}$ & $18.1 \mathrm{~b}$ \\
\hline $\begin{array}{l}\text { Total volatile abundanc } \\
\text { (peak height, } \times 10^{4} \text { ) }\end{array}$ & $3.6 \mathrm{~b}$ & $4.2 \mathrm{~b}$ & $25.6 \mathrm{a}$ & $33.6 \mathrm{a}$ & $0.7 \mathrm{~d}$ & $1.7 \mathrm{~cd}$ & $2.6 \mathrm{bc}$ & $4.0 \mathrm{~b}$ \\
\hline \multicolumn{9}{|l|}{ Expt. III } \\
\hline Ethyl acetate & $1.1 \mathrm{c}$ & $20.5 \mathrm{~b}$ & $394.6 \mathrm{a}$ & $403.4 \mathrm{a}$ & $0.8 \mathrm{c}$ & $1.4 \mathrm{c}$ & $0.9 \mathrm{c}$ & $15.8 \mathrm{~b}$ \\
\hline Ethyl propionate & $1.3 \mathrm{~d}$ & $24.4 \mathrm{~b}$ & $115.8 \mathrm{a}$ & $105.2 \mathrm{a}$ & $0.4 \mathrm{e}$ & $0.3 \mathrm{e}$ & $0.8 \mathrm{~d}$ & $12.8 \mathrm{c}$ \\
\hline Ethyl butanoate & $2.0 \mathrm{bcd}$ & $14.6 \mathrm{a}$ & $2.2 \mathrm{bcd}$ & $13.1 \mathrm{a}$ & $1.3 \mathrm{~d}$ & $3.5 \mathrm{bc}$ & $1.3 \mathrm{~d}$ & $5.6 \mathrm{ab}$ \\
\hline Ethyl hexanoate & $0.60 \mathrm{a}$ & $0.12 \mathrm{~cd}$ & $0.38 \mathrm{ab}$ & $0.16 \mathrm{c}$ & $0.10 \mathrm{~d}$ & $0.22 \mathrm{bc}$ & $0.26 \mathrm{~b}$ & $0.11 \mathrm{~cd}$ \\
\hline Butyl acetate & $35.7 \mathrm{a}$ & $17.6 \mathrm{ab}$ & $18.5 \mathrm{ab}$ & $18.1 \mathrm{ab}$ & $0.2 \mathrm{c}$ & $0.6 \mathrm{c}$ & $17.1 \mathrm{ab}$ & $11.8 \mathrm{~b}$ \\
\hline 2-methylbutyl acetate & $23.9 \mathrm{a}$ & $8.0 \mathrm{bc}$ & $22.8 \mathrm{a}$ & $11.1 \mathrm{~b}$ & $0.2 \mathrm{f}$ & $0.7 \mathrm{e}$ & $6.7 \mathrm{c}$ & $2.6 \mathrm{~d}$ \\
\hline Hexyl acetate & $3.19 \mathrm{a}$ & $0.21 \mathrm{bc}$ & $0.53 \mathrm{~b}$ & $0.12 \mathrm{c}$ & $0.01 \mathrm{e}$ & $0.03 \mathrm{e}$ & $0.46 \mathrm{~b}$ & $0.09 \mathrm{~d}$ \\
\hline Butyl butanoate & $2.34 \mathrm{a}$ & $0.06 \mathrm{c}$ & $0.83 \mathrm{~b}$ & $0.03 \mathrm{c}$ & $0.01 \mathrm{~d}$ & $0.01 \mathrm{~d}$ & $0.50 \mathrm{~b}$ & $0.01 \mathrm{~d}$ \\
\hline \multicolumn{9}{|l|}{ 2-methylbutyl } \\
\hline 3-methylbutanoate & $2.73 \mathrm{a}$ & $0.21 \mathrm{bc}$ & $0.48 \mathrm{~b}$ & $0.14 \mathrm{c}$ & $0.02 \mathrm{~d}$ & $0.01 \mathrm{~d}$ & $0.43 \mathrm{~b}$ & $0.04 \mathrm{~cd}$ \\
\hline Butyl hexanoate & $0.45 \mathrm{a}$ & $0.14 \mathrm{bcd}$ & $0.25 \mathrm{ab}$ & $0.14 \mathrm{bcd}$ & $0.11 \mathrm{~d}$ & $0.11 \mathrm{~d}$ & $0.20 \mathrm{bc}$ & $0.12 \mathrm{~cd}$ \\
\hline Ethanol $\left(\times 10^{3}\right)$ & $4.4 \mathrm{~b}$ & $3.6 \mathrm{~b}$ & $30.1 \mathrm{a}$ & $21.5 \mathrm{a}$ & $0.6 \mathrm{~d}$ & $0.7 \mathrm{~d}$ & $1.9 \mathrm{c}$ & $2.9 \mathrm{bc}$ \\
\hline Butanol & $28.4 \mathrm{a}$ & $11.5 \mathrm{~b}$ & $21.9 \mathrm{ab}$ & $13.5 \mathrm{~b}$ & $4.0 \mathrm{c}$ & $3.6 \mathrm{c}$ & $32.7 \mathrm{a}$ & $12.4 \mathrm{~b}$ \\
\hline $\begin{array}{l}\text { Total volatile abundanc } \\
\quad\left(\text { peak height, } \times 10^{4}\right)\end{array}$ & $5.5 \mathrm{~b}$ & $4.8 \mathrm{~b}$ & $18.4 \mathrm{a}$ & $16.1 \mathrm{a}$ & $0.9 \mathrm{~d}$ & $1.3 \mathrm{~d}$ & $2.4 \mathrm{~cd}$ & $3.0 \mathrm{c}$ \\
\hline
\end{tabular}

zPretreatments: ethanol vapor, $5 \mathrm{~mL} \cdot \mathrm{kg}^{-1}$ at $25^{\circ} \mathrm{C}$ for $24 \mathrm{~h}$; Heat, static air with $38^{\circ} \mathrm{C}$ and $>98 \%$ RH for $4 \mathrm{~d} ; 1$-MCP, 1 (Expt. I) or 0.625 (Expts. II and III) $\mu \mathrm{L} \cdot \mathrm{L}^{-1}$ at $20{ }^{\circ} \mathrm{C}$ for $18 \mathrm{~h}$.

y Samples for day 0 were obtained $2 \mathrm{~h}$ later after cutting and antibrowning-sanitizing diping.

xAverage of three replications. Mean separation by Duncan's multiple range test at the $5 \%$ level in same row. 
Table 3.Squared Mahalanobis distances between pretreatment means by GC headspace volatile and electronic nose data using conanical discriminant analysis. ${ }^{z}$

\begin{tabular}{|c|c|c|c|c|c|c|}
\hline \multirow[b]{2}{*}{ Paarameter } & \multicolumn{2}{|c|}{ Ethanol } & \multicolumn{2}{|c|}{ Heat } & \multicolumn{2}{|c|}{ 1-MCP } \\
\hline & $\mathrm{D}^{2}$ & Prob & $\mathrm{D}^{2}$ & Prob & $\mathrm{D}^{2}$ & Prob \\
\hline \multicolumn{7}{|c|}{ GC headspace } \\
\hline Control & 75.7 & $<0.0001$ & 27.5 & $<0.0001$ & 7.2 & 0.0355 \\
\hline Ethanol & & & 95.3 & $<0.0001$ & 79.4 & $<0.0001$ \\
\hline Heat & & & & & 16.3 & $<0.0001$ \\
\hline \multicolumn{7}{|c|}{ Electronic nose } \\
\hline Control & 136.6 & $<0.0001$ & 60.6 & $<0.0001$ & 7.0 & $<0.0001$ \\
\hline Ethanol & & & 183.2 & $<0.0001$ & 137.2 & $<0.0001$ \\
\hline Heat & & & & & 35 & $<0.0001$ \\
\hline
\end{tabular}

2Pretreatments include ethanol vapor, $5 \mathrm{~mL} \cdot \mathrm{kg}^{-1}$ at $25^{\circ} \mathrm{C}$ for $24 \mathrm{~h}$; heat, static air with $38^{\circ} \mathrm{C}$ and $>98 \% \mathrm{RH}$ for $4 \mathrm{~d} ; 1-\mathrm{MCP}, 1$ (Expt. I) or 0.625 (Expts. II and III) $\mu \mathrm{L} \cdot \mathrm{L}^{-1}$ at $20^{\circ} \mathrm{C}$ for $18 \mathrm{~h}$.

$\mathrm{D}^{2}$ : Pairwise squared distance to pretreatments.

Prob: probability > Mahalanobis distance for squared distance to pretreatments.

Table 4. Hedonic ratings for sensory attributes of of fresh-cut apples kept at $5.5^{\circ} \mathrm{C}$ for $7 \mathrm{~d}$. Intact fruit were treated with ethanol vapor, heat or left untreated and were cold-stored before cutting. ${ }^{2}$

\begin{tabular}{|c|c|c|c|c|c|c|c|}
\hline \multirow[b]{3}{*}{ Expt. } & \multirow[b]{3}{*}{ Attribute } & \multicolumn{6}{|c|}{ Pretreatment } \\
\hline & & \multicolumn{2}{|c|}{ Control } & \multicolumn{2}{|c|}{ Ethanol } & \multicolumn{2}{|c|}{ Heat } \\
\hline & & $\overline{\text { Day } 0}$ & Day 7 & $\overline{\text { Day } 0}$ & Day 7 & Day 0 & Day 7 \\
\hline \multirow[t]{5}{*}{$\bar{I}$} & Apple-like flavor & $7.6 \mathrm{a}^{\mathrm{y}}$ & $7.1 \mathrm{a}$ & $6.0 \mathrm{~b}$ & $6.1 \mathrm{~b}$ & $4.9 \mathrm{c}$ & $5.6 \mathrm{bc}$ \\
\hline & Alter flavor & $3.3 \mathrm{~b}$ & $3.0 \mathrm{~b}$ & $4.3 \mathrm{c}$ & $4.4 \mathrm{c}$ & $2.6 \mathrm{ab}$ & $1.5 \mathrm{a}$ \\
\hline & Acidity & $4.2 \mathrm{a}$ & $4.8 \mathrm{a}$ & $4.3 \mathrm{a}$ & $4.5 \mathrm{a}$ & $3.8 \mathrm{a}$ & $4.6 \mathrm{a}$ \\
\hline & Firmness & $8.1 \mathrm{a}$ & $7.6 \mathrm{a}$ & $7.4 \mathrm{a}$ & $7.4 \mathrm{a}$ & $6.2 \mathrm{~b}$ & $5.9 \mathrm{~b}$ \\
\hline & Preference & $7.5 \mathrm{a}$ & $7.1 \mathrm{a}$ & $5.6 \mathrm{c}$ & $5.2 \mathrm{c}$ & $6.7 \mathrm{~b}$ & $6.4 \mathrm{~b}$ \\
\hline \multirow[t]{5}{*}{ II } & Apple-like flavor & $6.9 \mathrm{a}$ & $7.1 \mathrm{a}$ & $6.4 \mathrm{~b}$ & $5.9 \mathrm{~b}$ & $5.7 \mathrm{~b}$ & $5.7 \mathrm{~b}$ \\
\hline & Alter flavor & $3.3 \mathrm{a}$ & $3.5 \mathrm{a}$ & $4.3 \mathrm{~b}$ & $4.4 \mathrm{~b}$ & $3.3 \mathrm{a}$ & $2.8 \mathrm{a}$ \\
\hline & Acidity & $5.2 \mathrm{a}$ & $5.2 \mathrm{a}$ & $4.5 \mathrm{~b}$ & $3.9 \mathrm{~b}$ & $3.8 \mathrm{~b}$ & $4.3 \mathrm{~b}$ \\
\hline & Firmness & $6.7 \mathrm{a}$ & $7.0 \mathrm{a}$ & $5.4 \mathrm{~b}$ & $4.0 \mathrm{~b}$ & $6.3 \mathrm{ab}$ & $6.1 \mathrm{ab}$ \\
\hline & Preference & $7.6 \mathrm{a}$ & $7.1 \mathrm{a}$ & $5.2 \mathrm{c}$ & $5.3 \mathrm{c}$ & $6.0 \mathrm{~b}$ & $6.3 \mathrm{~b}$ \\
\hline \multirow[t]{5}{*}{ III } & Apple-like flavor & $8.1 \mathrm{a}$ & $7.5 \mathrm{a}$ & $5.2 \mathrm{~b}$ & $5.8 \mathrm{~b}$ & $5.6 \mathrm{~b}$ & $5.7 \mathrm{~b}$ \\
\hline & Alter flavor & $1.3 \mathrm{a}$ & $2.4 \mathrm{a}$ & $4.8 \mathrm{~b}$ & $3.4 \mathrm{ab}$ & $2.3 \mathrm{a}$ & $2.5 \mathrm{a}$ \\
\hline & Acidity & $4.9 \mathrm{a}$ & $5.2 \mathrm{a}$ & $4.1 \mathrm{~b}$ & $3.7 \mathrm{~b}$ & $4.2 \mathrm{~b}$ & $2.6 \mathrm{~b}$ \\
\hline & Firmness & $7.6 \mathrm{a}$ & $6.8 \mathrm{a}$ & $5.9 \mathrm{~b}$ & $4.0 \mathrm{~b}$ & $5.4 \mathrm{~b}$ & $4.9 \mathrm{~b}$ \\
\hline & Preference & $8.1 \mathrm{a}$ & $7.1 \mathrm{a}$ & $5.2 \mathrm{~b}$ & $6.0 \mathrm{~b}$ & $5.9 \mathrm{~b}$ & $5.5 \mathrm{~b}$ \\
\hline
\end{tabular}

zPretreatments: ethanol vapor, $5 \mathrm{~mL} \cdot \mathrm{kg}^{-1}$ at $25^{\circ} \mathrm{C}$ for $24 \mathrm{~h}$; Heat, static air with $38^{\circ} \mathrm{C}$ and $>98 \%$ RH for $4 \mathrm{~d}$; 1 -MCP, 1 (Expt. I) or 0.625 (Expts. II and III) $\mu \mathrm{L} \cdot \mathrm{L}^{-1}$ at $20^{\circ} \mathrm{C}$ for $18 \mathrm{~h}$.

yAverage of 15 replications (panelists). Mean separation by Duncan's multiple range test at the 5\% level in same row.

researchers for heat-treated intact fruit (Conway et al., 1994; Klein et al., 1990; Porritt and Lidster, 1978). Cell wall studies found less soluble pectin and more insoluble pectin in heat-treated fruit (Klein et al., 1990). Less calcium was present in the soluble pectin and more was bound to the cell wall in heat-treated fruit (Lurie and Klein, 1992a).

SENSORY. Only ethanol-pretreated, heat-pretreated, and nonpretreated control slices were tested for taste/flavor since 1-MCP had not yet been approved at the time of the panel test, and testing was only done after $7 \mathrm{~d}$ of storage. By $14 \mathrm{~d}$, only the ethanol-pretreated slices were still visually acceptable. The panel test results showed that the slices of nonpretreated controls were preferred over slices from the pretreated fruit, and that there was no change in any quality attribute during the first week of storage for any of the treatments (Table 4). This is interesting because levels of many important aroma components, such as the ethyl esters (Ueda et al., 1993; Young et al., 1996) changed during this time period (Table 2), as well as titratable acidity for nonpretreated controls (Fig. 5).

Ethanol pretreatment of intact fruit led to generally lower ratings for apple-like flavor, acidity, and firmness (Expts. II and III) in the subsequent slices compared to nonpretreated control slices, and generally higher ratings for altered flavor than control and heat-pretreated slices (Table 4). The titratable acidity for ethanol-pretreated slices was lower than that of controls initially, but by day 7, control slices showed a similar level of acidity (Fig. 5). Aroma compounds were overall higher in ethanol-pretreated slices (especially ethanol and some ethyl esters) compared to controls (Table 2), explaining differences in apple-like flavor and altered flavor from control slices. Interestingly, even though firmness rating of the ethanol-pretreated slices was lower than that of controls in the sensory test (Table 3), instrumental analysis of firmness showed no difference or slightly lower firmness for ethanol-pretreated slices initially and slightly higher firmness after $7 \mathrm{~d}$ of storage compared to nonpretreated controls (Fig. 6).

Heat-pretreated slices were also generally scored lower for apple-like flavor, acidity, and preference than controls and these slices were, in fact, found to be lower in both aroma volatiles (Table 2) and titratable acidity (Fig. 5) compared to controls. It is interesting that the panelists rated heat-pretreated slices less firm 
or the same as nonpretreated control slices when instrumental compression tests indicated that heat-pretreated slices were firmer. Conway et al. (1994) using compression tests found the heated apples to be tougher, while Lurie and Nussinovich (1996), using Instron compression and shearing measurements, found heated intact apples to be crisper than nonheated control. These results indicate that the firmness, as felt by teeth and mouth, is a sensitive and complex trait that requires more than simple compression analysis to measure. In addition, panelists may confuse crispness and firmness. However, marketability of slices was determined to have a threshold level of 5, thus, all slices were still marketable after 1 week of storage.

In conclusion, our data show that pretreating intact 'Gala' apple with ethanol and heat prolongs shelf life of the fresh-cut products by slowing down respiration and ethylene production of cut slices, and inhibiting decay development on the cut surface, despite aroma loss and/or flavor changes. Pretreating intact apples with 1-MCP, while delaying acidity and firmness loss, promoted decay development and shortened the shelf life of 'Gala' apple slices.

\section{Literature Cited}

Abdi, N., W.B. McGlasson, P. Holford, M. Williams, and Y. Mizrahi. 1998. Response of climacteric and suppressed-climacteric plums to treatment with propylene and 1-methylcyclopropene. Postharvest Biol. Technol. 14:29-39.

Atta Aly, M.A. 1992. Effect of high temperature on ethylene biosynthesis by tomato fruits. Postharvest Biol. Technol. 2:19-24.

Bai, J. and E.A. Baldwin. 2002. Postprocessing dip maintains quality and extends the shelf life of fresh-cut apple. Proc. Fla. State Hort. Soc. 115:297-300.

Bai, J., R.H. Hagenmaier, and E.A. Baldwin. 2002. Volatile response of four apple varieties with different coatings during marketing at room temperature. J. Agr. Food Chem. 50:7660-7668.

Bai, J., R.A. Saftner, A.E. Watada, and Y.S. Lee. 2001. Modified atmosphere maintains quality of fresh-cut cantaloupe (Cucumis melo L.). J. Food Sci. 66:1207-1211.

Baldwin, E.A., M.O. Nisperos, X. Chen, and R.D. Hagenmaier. 1996. Improving the storage life of cut apple and potato with edible coating. Postharvest Biol. Technol. 9:151-163.

Baritelle, A.L., G.M. Hyde, J.K. Fellman, and J. Varith. 2001. Using 1MCP to inhibit the influence of ripening on impact properties of pear and apple tissues. Postharvest Biol. Technol. 23:153-160.

Beaulieu, L.C. and E.A. Baldwin. 2002. Flavor and aroma of fresh-cut fruits and vegetables, p. 391-425. In: O. Lamikanra (ed.). Fresh-cut fruits and vegetables: Science, technology, and market. CRC Press, Boca Raton, Fla.

Beaulieu, L.C. and M.E. Saltveit. 1997. Inhibition or promotion of tomato fruit ripening by acetaldehyde and ethanol is concentration dependent and varies with initial fruit maturity. J. Amer. Soc. Hort. Sci. 122:392-398.

Bent, A.F., R.W. Innes, J.R. Ecker, and B.J. Staskawicz. 1992. Disease development in ethylene-insensitive Arabidopsis thaliana infected with virulent and avirulent $P$ seudomonas and Xanthomonas pathogens. Mol. Plant-Microbe Interactions 5:372-378.

Biggs, M.S., W.R. Woodson, and A.K. Handa. 1988. Biochemical basis of high temperature inhibition of ethylene biosynthesis in ripening tomato fruits. Physiol. Plant. 72:572-578.

Chan, H.T. 1986. Heat inactivation of the ethylene forming enzyme system in cucumber. J. Food Sci. 51:1491-1493.

Chan, H.T. 1991. Ripeness and tissue depth effects on heat inactivation of papaya ethylene forming enzyme. J. Food Sci. 56:996-998.

Chervin, C., J. Raynal, N. Andre, A. Bonneau, and P. Westercamp. 2001. Combining controlled atmosphere storage and ethanol vapors to control superficial scald of apple. HortScience 36:951-952.
Conway, W.S., C.F. Sams, C.Y. Wang, and J.A. Abbott. 1994. Additive effects of postharvest calcium and heat treatment on reducing decay and maintaining quality in apples. J. Amer. Soc. Hort. Sci. 119:49-53.

Dunlap, J.R., S.E. Lingle, and G.E. Lester. 1990. Ethylene production in netted muskmelon subjected to postharvest heating and refrigerated storage. HortScience 25:207-209.

Eaks, I.L. 1978. Ripening, respiration, and ethylene production of "Hass" avocado fruits at $20{ }^{\circ} \mathrm{C}$ to $40{ }^{\circ} \mathrm{C}$. J. Amer. Soc. Hort. Sci. 103:576-578.

Environmental Protection Agency. 2002. 1-Methylcyclopropene; exemption from the requirement of a tolerance. Fed. Reg. 6748796-48800,

Fallik, E., D.D. Archbold, T.R. Hamilton-Kemp, J.H. Loughrin, and R.W. Collins. 1997. Heat treatment temporarily inhibits aroma volatile compound emission from Golden Delicious apples. J. Agr. Food Chem. 45:4038-4041.

Fan, X., L. Argenta, and J.P. Mattheis. 2000. Inhibition of ethylene action by 1-methylcyclopropene prolongs storage life of apricots. Postharvest Biol. Technol. 21:135-142.

Fan, X., S. Blankenship, and J.P. Mattheis. 1999. 1-Methylcyclopropene inhibits apple ripening. J. Amer. Soc. Hort. Sci. 124:690-695.

Fan, X. and J.P. Mattheis. 1999. Impact of 1-methylcyclopropene and methyl jasmonate on apple volatile production. J. Agr. Food Chem. 47:2847-2853.

Garrett, E.H. 2002. Fresh cut produce: Tracks and trends, p. 1-10. In: O. Lamikanra (ed.). Fresh-cut fruits and vegetables: Science, technology, and market. CRC Press, Boca Raton, Fla.

Ghahramani, F. and K.J. Scott. 1998. The action of ethanol in controlling superficial scald of apples. Austral. J. Agr. Res. 49:199-205.

Golding, J.B., D. Shearer, S.G. Wyllie, and W.B. McGlasson. 1998. Application of 1-MCP and propylene to identify ethylene-dependent ripening processes in mature banana fruit. Postharvest Biol. Technol. 14:87-98.

Gong, Y., X. Fan, and J. P. Mattheis. 2002. Responses of 'Bing' and 'Rainier' sweet cherries to ethylene and 1-methylcyclopropene. J. Amer. Soc. Hort. Sci. 127:831-835.

Itai, A., K. Tanabe, F. Tamura, and T. Tanaka. 2000. Isolation of cDNA clones corresponding to genes expressed during fruit ripening in Japanese pear (Pyrus pyrifolia Nakai): involvement of the ethylene signal transduction pathway in their expression. J. Expt. Bot. 51: 1163-1166.

Kelly, M.O. and M.E. Saltveit. 1988. Effect of endogenously synthesized and exogenously applied ethanol on tomato fruit ripening. Plant Physiol. 88:143-147.

Klein, J.D. 1989. Ethylene biosynthesis in heat treated apples, p. 184-190. In: H. Clijsters, M. de Proft, R. Marcelle, and M. van Pouche (eds.). Biochemical and physiological aspects of ethylene production in lower and higher plants. Kluwer, Dordrecht, The Netherlands.

Klein, J.D., S. Lurie, and R. Ben-Arie. 1990. Quality and cell wall components of 'Anna' and 'Granny Smith' apples treated with heat, calcium and ethylene. J. Amer. Soc. Hort. Sci. 115:954-958.

Ku, V.V.V., R.B.H. Wills, and S. Ben-Yehoshua. 1999. 1-Methylcyclopropene can differentially affect the postharvest life of strawberries exposed to ethylene. HortScience 34:119-120.

Lelièvre, J-M., L. Tichit, P. Dao, L. Fillion, Y-W. Nam, J-C. Pech, and A. Latché. 1997. Effects of chilling on the expression of ethylene biosynthetic genes in Passe-Crassane pear (Pyrus communis L.) fruits. Plant Mol. Biol. 33:847-855.

Liu, F.W. 1978. Modification of apple quality by high temperature. J. Amer. Soc. Hort. Sci. 103:730-732.

Lurie, S. 1998. Postharvest heat treatments. Postharvest Biol. Technol. 14:257-269.

Lurie, S., A. Handros, E. Fallik, and R. Shapira. 1996. Reversible inhibition of tomato fruit gene expression at high temperature. Plant Physiol. 110:1207-1214.

Lurie, S. and J.D. Klein. 1990. Heat treatment of ripening apples: differential effects on physiology and biochemistry. Physiol. Plant. 78: 181-186. 
Lurie, S. and J.D. Klein. 1992a. Calcium and heat treatments to improve storability of 'Anna' apple. HortScience 27:36-39.

Lurie, S. and J.D. Klein. 1992b. Ripening characteristics of tomatoes stored at $12 \mathrm{C}$ and $2 \mathrm{C}$ following a prestorage heat treatment. Scientia Hort. 51:55-64.

Lurie, S. and A. Nussinovich. 1996. Compression characteristics, firmness, and texture perception of heat treated and unheated apples. Intl. J. Food Sci. Technol. 31:1-5.

Maxie, E., G. Mitchell, N. Sommer, G. Snyder, and H. Rae. 1974. Effects of elevated temperatures on ripening of 'Bartlett' pear. J. Amer. Soc. Hort. Sci. 99:344-349.

Mattheis, J.P., J.K. Fellman, P.M. Chen, and M.E. Patterson. 1991. Changes in headspace volatiles during physiological development of Bisbee Delicious apple fruit. J. Agr. Food Chem. 39:1902-1906.

Mencarelli, F., P. Savarese, and M.E. Saltveit, Jr. 1991. Ripening of kiwifruit exposed to ethanol and acetaldehyde vapors. HortScience 26:566-569.

Nakatsuka, A., S. Shiomi, Y. Kubo, and A. Inaba. 1997. Expression and internal feedback regulation of ACC synthase and ACC oxidase genes in ripening tomato fruit. Plant Cell Physiol. 38:1103-1110.

O'Bieme, D. 1990. Some effects of modified atmosphere packaging and vacuum packaging in combination with antioxidants on quality and storage life of ready-to-use chilled apples slices, p. 221-229. In: P. Zeuthen, J. Chefteol, C. Eriksson, T. Gormley, P. Linko, and K. Paulus (eds.). Processing and quality of foods. vol. 3. Elsevier Applied Science, London,

Paull, R.E. and N.J. Chen. 1990. Heat shock response in field grown ripening papaya fruit. J. Amer. Soc. Hort. Sci. 115:623-631.

Perera, C., L. Balchin, M. Tian, E.A. Baldwin, and R. Stanley. 2003. Effect of 1-methylcyclopropene on the quality of fresh-cut 'Pacific Rose' apple slices. J. Food Sci. 68:1910-1914.

Picton, S. and D. Grierson. 1988. Inhibition of expression of tomato ripening genes at high temperature. Plant Cell Environ. 11:265-272.

Porat, R., B. Weiss, L. Cohen, A. Daus, R. Goren, and S. Droby. 1999. Effects of ethylene and 1-methylcyclopropene on the postharvest qualities of 'Shamouti' oranges. Postharvest Biol. Technol. 15:155-163.

Porritt, S.W. and P.D. Lidster. 1978. The effect of prestorage heating on ripening and senescence of apples during cold storage. J. Amer. Soc. Hort. Sci. 103:584-587.

Rupasinghe, H.P.V., D.P. Murr, G. Paliyath, and L. Skog. 2000. Inhibitory effect of 1-MCP on ripening and superficial scald development in 'McIntosh' and 'Delicious' apples. J. Hort. Sci. Biotechnol. 75: 271-276.

Saftner, R.A., J.H. Bai, J.A. Abbott, and Y.S. Lee. 2003a. Use of sanitary dips containing calcium propionate, calcium chloride or a calcium amino acid chelate to maintain quality and shelf stability of fresh-cut honeydew. Postharvest Biol. Technol. 29: 257-269.
Saftner, R.A., J.A. Abbott, C.L. Barden, and W.S. Conway. 2003b. Effect of 1-methylcyclopropene and heat treatments on ripening and postharvest decay in 'Golden Delicious' apples. J. Amer. Soc. Hort. Sci. 128:120-127.

Saltveit, Jr., M.E. and F. Mencarelli. 1988. Inhibition of ethylene synthesis and action in ripening tomato fruit by ethanol vapors. J. Amer. Soc. Hort. Sci. 113:572-276.

Saltveit, Jr., M.E. and A.R. Sharaf. 1992. Ethanol inhibits ripening of tomato fruit harvested at various degrees of ripeness without affecting subsequent quality. J. Amer. Soc. Hort. Sci. 117:793-798.

SAS Institute. 1999. SAS/Stat user's guide. version 8. SAS Inst., Cary, N.C.

Scott, K.J., C.M.C. Yuen, and F. Ghahramani. 1995. Ethanol vapour-A new anti-scald treatment for apples. Postharvest Biol. Technol. 6: 201-208

Seymour, G.B., P. John, and A.K. Thompson. 1987. Inhibition of degreening in the peel of bananas repined at tropical temperatures. II. Role of ethylene, oxygen and carbon dioxide. Ann. Appl. Biol. 110: 153-161.

Sisler, E.C. and M. Serek. 1997. Inhibition of ethylene responses in plants at the receptor level: Recent developments. Physiol. Plant. 100:577-582.

Tsuji, M., H. Harakawa, and Y. Komiyama. 1984. Changes in shelf life and quality of plum fruit during storage at high temperatures. J. Jpn. Soc. Hort. Sci. 52:469-473.

Ueda, Y., J. Bai, and H.Yoshioka. 1993. Effects of polyethylene packaging on flavor retention and volatile production of Starking Delicious apple. J. Jpn. Soc. Hort. Sci. 62:207-213.

Wang, C.Y. and J. G. Buta. 2003. Maintaining quality of fresh-cut kiwifruit with volatile compounds. Postharvest Biol. Technol. 28:181-186.

Watada, A.E. and D.R. Massey. 1981. A compact automatic system for measuring $\mathrm{CO}_{2}$ and $\mathrm{C}_{2} \mathrm{H}_{4}$ evolution by harvested horticulture crops. HortScience 16:39-41.

Watkins, C.B., J.F. Nock, and B.D.Whitaker. 2000. Responses of early, mid and late season apple cultivars to postharvest application of 1methylcyclopropene (1-MCP) under air and controlled atmosphere conditions. Postharvest Biol. Technol. 19:17-32.

Yang, R.F., T.S. Cheng, and R.L. Shewfelt. 1990. The effect of high temperature and ethylene treatment on the ripening of tomatoes. J. Plant Physiol. 136:368-372.

Yanuriati, A., G.P. Savage, and R.N. Rowe. 1999. The effects of ethanol treatment on the metabolism, shelf life and quality of stored tomatoes at different maturities and temperatures. J. Sci. Food Agr. 79: 995-1002.

Young, H., J.M. Gilber, S.H. Murray, and R.D. Ball. 1996. Causal effects of aroma compounds on Royal Gala apple flavors. J. Sci. Food Agr. 71:329-336. 